\title{
Determinan Keberhasilan Wirausaha Mahasiswa di Kota Tangerang Selatan
}

\author{
Rahman Faisal ${ }^{1)}$, Lukman Anthoni ${ }^{2)}$ \\ 1) Universitas Pamulang, Indonesia, dosen01429@unpam.ac.id \\ 2) Universitas Pamulang, Indonesia, dosen01430@unpam.ac.id
}

\begin{abstract}
Abstrak. Tujuan dalam penelitian ini agar menemukan dan mempelajari dampak pendidikan kewirausahaan juga minat berwirausaha, motivasi berwirausaha dan keberhasilan wirausaha mahasiswa di Kota Tangerang Selatan. Penelitian ini menggunakan metode quantitaif deskripsi dengan menggunakan PLS-SEM dalam menganalisis data penelitian, sementara software yang digunakan yaitu Smart-PLS. Data dalam penelitian ini berupa kuesioner yang diisikan oleh responden yang sedang mempelajari dan telah mempelajari mata kuliah kewirausahaan di lingkungan Perguruan Tinggi di Kota Tangerang Selatan dan juga sebagai penggunaan contoh/sampel. Metode Slovin digunakan sebagai teknik dari sampel yang diambil dengan total sampel sebanyak 417 mahasiswa/l yang sedang dan/atau telah menyelesaikan mata kuliah kewirausahaan. Hasilnya menunjukan bahwa pendidikan kewirausahaan $(X)$ memiliki dampak atau pengaruh yang signifikan terhadap Minat $(\mathrm{Y} 1)$ sebesar 0.517 , Pendidikan kewirausahaan $(\mathrm{X})$ juga memiliki pengaruh terhadap motivasi (Y2) sebesar 0.308. Sementara itu Minat Berwirausaha (Y1) berpengaruh signifikan terhadap Kesuksesan kewirausahaan Mahasiswa (Z) sebesar 0.380 . Selanjutnya Motivasi berwirausaha (Y2) juga memiliki pengaruh signifikan terhadap kesuksesan kewirausahaan mahasiswa $(Z)$ sebesar 0.447 . Jadi dapat disimpulkan bahwa dalam penelitian ini ditemukan pengaruh yang siginifikan dimana pendidikan kewirausahaan dipengaruhi oleh minat dan motivasi serta kesuksesan kewirausahaan dipengaruhi oleh minat dan motivasipara mahasiswa/l di Kota Tangerang Selatan.
\end{abstract}

Keywords: Pendidikan Kewirausahaan; ,Minat Berwirausaha; Motivasi Berwirausaha; Kesuksesan Wirausaha

\begin{abstract}
The research aims to found the learning impact of entrepreneurship education, entrepreneurial interest, and entrepreneurial motivation on student entrepreneurial success in South Tangerang City. This research uses descriptive quantitative method. Data acquire based on questionnaires filled in by respondents who are students at universities or colleges who live in the city of South Tangerang as the research samples. The population used in this study was determined to be students and female students who have received entrepreneurship courses. The sample in took in this research by the Slovin method. The total sample used in this study was 417 students who are currently taking higher and moderate education or who have received entrepreneurship learning material. Meanwhile, data analysis performed used by descriptive statistics and PLS-Structural Equation Modelling (PLS-SEM), SmartPLS software used. This showed the result that entrepreneurship education $(X)$ had significant effect to $Y 1$ (Interest) of 0.517 and entrepreneurship education $(X)$ had significant effect to (Y2) Motivation was 0.308. Meanwhile (Y1) Interest entrepreneurship had significant effect to (Z) Entrepreneurial Success is 0.380 while (Y2) had 0.447 significant effects to (Z). The final result, it was found that entrepreneurship education has significance for business interest and entrepreneurial motivation and also has significance for the entrepreneurial success of students in South Tangerang City.
\end{abstract}

Keywords: Entrepreneurship Education; Entrepreneurial Interest; Entrepreneurial Motivation; Entrepreneurial Success. 


\section{A. PENDAHULUAN}

Sesuai dengan PP Republik Indonesia No. 41 Tahun 2011 yang menabarkan bagaimana Pengembangan Kewirausahaan dan Kepeloporan Pemda, Serta Penyediaan Prasarana dan Sarana Kepemudaan, pada Bab I Ketentuan Umum dalam Pasal 1 butir ke4 yaitu Pengembangan kewirausahaan pemuda adalah kegiatan mengembangkan potensi keterampilan dan kemandirian berusaha. Serta pada Bab II tentang Tugas dan tanggung jawab pada pasal 2, butir ke-1 yaitu Pengembangan kewirausahaan dan kepeloporan pemuda, serta penyediaan prasarana dan sarana kepemudaan merupakan tugas dan tanggung jawab Pemerintah, pemerintah daerah provinsi, dan pemerintah daerah kabupaten/kota.Berdasarkan data dari Dinas Koperasi dan Usaha Kecil Menengah (UKM) pada tahun 2019 di Kota Tangerang Selatan terdata sebanyak 26.700 UKM, namun sebanyak $60 \%$ lebih banyak bergerak dibidang Kuliner.

Hal ini dilihat dari bagaimana perbandingan wirausaha jika dilihat dari Badan Pusat Statistik (BPS) secara nasional, maka data wirausaha naik sebesar 3,10 persen. Jika dibandingkan periode lalu sebesar 1,67 persen dari total sebanyak 225 juta jumlah penduduk Indonesia. sudah seharusnya pengembangan kewirausahaan pemuda dalam hal ini mahasiswa yang merupakan kegiatan positif untuk menumbuh-kembangkan potensi baik dari sisi keterampilan dan kemandirian berusaha. Selain itu juga diperlukan pengembangan kewirausahaan dan kepeloporan pemuda. Mahasiswa dalam hal ini termasuk salah satu pemuda dan pelopor untuk memulai berwirausaha. Ragam kegiatan wirausaha di setiap kampus tentunya berbeda satu sama lain. Hal ini dipicu dari perbedaan aturan, mekanisme dan standar yang ditetapkan dari masing-masing kampus tempat Mahasiswa menimba ilmu. Dengan demikian diperlukan adanya pola pendekatan pendidikan kewirausahaan untuk Mahasiswa.Hal tersebut tak lepas dari baik sumber daya modal yang diperlukan dalam berwirausaha, tentunya juga diperlukan pendampingan, pelatihan bagaimana berwirausaha.Perlunya pendekatan pendidikan kewirausahaan yang efektif dan baik, diharapkan dapat memberikan dampak positif terhadap keinginan untuk berwirausaha.

Minat sejatinya dapat dipupuk selama mengeyam pendidikan baik formal maupun informal. Dampak minimnya minat Mahasiswa dalam berwirausahasalah satunya karena kurangnya keilmuan, pelatihan, akses permodalan karena tidak ada jaminan dari perbankan untuk usaha serta perhatian Pemerintah dalam hal ini Pemerintahan Kota Tangerang Selatan. Selain itu juga pola pikir Mahasiswa bisa jadi masih belum tumbuh secara baik untuk berfikir kritis, maju dan mandiri.Namun tentunya dengan pendekatan pendidikan kewirausahaan yang baik diharapkan mampu menarik minat dan motivasi untuk berwirausaha. Dengan demikian motivasi Mahasiswa untuk berwirausaha juga dapat dilihat bagaimana. Salah satu motivasi para Mahasiswa mau berwirausaha tentunya menginginkan adanya perbaikan kondisi ekonomi mereka. Selain itu, salah satu keberhasilan berwirausaha tidak lepas hanya pada pendidikan baik formal maupun informal, motivasi, minat yang mempengaruhi.

Berangkat dari fenomena tersebut maka tujuan khusus pada kajian yang dilakukan yaitu agar diketahui dan dianalisis mengevaluasi bagaimana pendidikan kewirausahaan yang efektif dan kedepannya dapat diketahui minat serta motivasi Mahasiswa sehingga dapat mengukur tingkat keberhasilan wirausahanya. Pendekatan dari pendidikan kewirausahaan memiliki dampak pada minat dan motivasi dalam berwirausaha. Urgensi penelitian jika dalam pendekatan pendidikan kewirausahaan tidak efektif, dalam proses belajar dan mengajar khususnya pada bidang kewirausahaan belum dapat memberikan dampak positif terhadap minat dan keberhasilan mahasiswa dalam berwirausaha. Oleh 
karena itu, pendekatan pendidikan yang seperti apa yang diharapkan dapat membantu dan meningkatkan minat dan motivasi mahasiswa untuk berwirausaha sehingga berhasil.

Pendidikan Kewirausahaan, menurut Wisnu (2015) pendidikan kewirausahaan bertujuan untuk membentuk manusia secara utuh sebagai insan yang memiliki sebuah karakter, pemahaman dan keterampilan. Menurut Wibowo (2011) pendidikan kewirausahaan merupakan cara atau upaya untuk menumbuhkan jiwa dan mental kewirausahaan bagi seseorang melalui institusi pendidikan maupun institusi lain, seperti lembaga pelatihan, training dan sebagainya. Sementara menurut Endang Mulyani (2011), beberapa indikator penilaian pendidikan kewirausahaan, antara lain: (1) kreatif; (2) Inovatif; (3) mandiri; (4) realistis dan (5) komunikatif

Minat Wirausaha, jika dilihat dari Kamus Besar Bahasa Indonesia (KBBI) minat adalah kecenderungan hati yang tinggi terhadap sesuatu; gairah; keinginan. Minat seseorang pada suatu objek yang umumnya diawali oleh kecenderungan suasana perasaan seseorang pada objek tersebut. Santoso (1993 dalam Agustina dan Sularto, 2011) memberikan pengertian minat wirausaha sebagai gejala psikis untuk memusatkan perhatian dan berbuat sesuatu terhadap wirausaha itu dengan perasaan senang dikarenakan membawa manfaat bagi dirinya. Seseorang yang berminat terhadap wirausaha akan memiliki kecenderungan hati untuk menciptakan suatu usaha untuk diatur, menanggung risiko, mengorganisir dan mengembangkan usaha yang telah diciptakan tersebut (Subandono, 2017).Alma (2013) menyampaikan bahwa minat berwirausaha dipengerahui oleh beberapa faktor, yaitu faktor lingkungan keluarga, lingkungan pendidikan dan kepribadian. Sehingga minat akan tumbuh dan berkembang sesuai dengan faktor yang mempengaruhinya.

Motivasi Wirausaha menurut Kamus Besar Bahasa Indonesia (KBBI) menjelaskan tentang motivasi merupakan rangsangan yang kuat yang timbul dimasing-masing individu yang sadar ata tanpa disadari dapat dilakukan sebagai tindakan dengan ketentuan tertentu. Gemima et al. (2016) menyampaikan motivasi usaha adalah suatu sukarela agar dapat berusaha semaksimal guna mencapai tujuan yang diutamakan dimana memiliki dampak dari kemampuan usaha untuk memuaskan beberapa kebutuhan individu. Motivasi merupakan dorongan yang kuat dari dalam diri seseorang untuk memulai mengkatualisasi potensi diri untuk berfikir kreatif dan inovatif dalam menciptakan produk baru serta bernilai tambah guna kepentingan bersama (Huarng et al. 2018). Faktor yang mempengaruhi motivasi wirausaha menurut Tuskeroh (2013) antara lain: (1) rasa percaya diri; (2) inovatif; (3) memiliki jiwa kepemimpinan; (4) efektif dan efisien; dan (5) berorientasi masa depan.

Keberhasilan Wirausaha,pengertian tentang keberhasilan usaha menurut Moch. Kohar Mudzakar (1998) merupakan suatu kondisi dapat digambarkan dimana kondisinya yang sederajat atau sekelasnya. Dalam pemahaman lain, keberhasilan wirausaha merupakan kegiatan dapat dikerahkan oleh tenaga serta pikiran untuk perubahan yang lebih baik dan bertambah maju ke depan, baik dari sudut kualitatif dan kuantitatif sesuai tujuan yang telah ditetapkan di awal. Menurut Suryana (2009) indikator keberhasilan wirausaha meliputi: (1) modal; (2) pendapatan; (3) volume penjualan; (4) output produksi; dan (5) tenaga kerja. Selanjutnya Suryana (2013) menyampaikan 3 faktor penyebab keberhasilan seorang wirausaha: (1) kemampuan serta kemauan; (2) tekad dan kerja keras; (3) kesempatan dan peluang.Berangkat dari latar belakang penelitian di atas, menarik untuk melihat "Determinan Keberhasilan Wirausaha yang dikaji yaitu pada pendidikan kewirausahaan, minat dan motivasidapat memberikan tingkat keberhasilan dalam berwirausaha pada mahasiswa di Kota Tangerang Selatan" yang telah menerima dan/atau mengenyam pendidikan kewirausahaan. 


\section{B. KAJIAN LITERATUR}

Kewirausahaan secara konsep dimana pengusaha/wirausahawan secara langsung dan/atau tidak langsung memiliki bakat /tekad yang digabungkan semua sumber daya baik sumber daya alam, sumber daya manusia maupun sumber daya modal serta sumber daya lainnya. Pengolaan sumber daya tersebut diubah menjadi kreatifitas serta inovasi baik produk maupun jasa dimana setiap usaha yang dilakukan terdapat resiko antara satu dengan yang lainnya. Menurut Rifkan (2017) dikatakan bahwa kewirausahaan adalah sebuah tahapan dan/atau proses agar dapat membuat suatu produk/jasa yang dalam prosesnya membutuhkan waktu dan usaha yang dilakukan dimana terdapat resiko yang dapat terjadi kapan saja. Lebih jauh, Rifkan (2017) menjabarkan bahwa terdapat 4 dasar yang menjadi aspek yang sejatinya terdapat pada diri pengusaha. Dikemukakan oleh Schumpeter dalam Suryana dan Bayu, (2010:27) dikemukakan pendapatnya mengenai wirausaha yaitu seorang yang melakukukan lompatan pada system ekonomi dengan membuat produk/jasa yang ada dalam satu naungan sebuah perkumpulan organisasi yang terukur, terarah sehingga membuat suatu produk baru lagi. Sementara menurut Prawirokusumo, (2010 : 26) mendefinisikan bahwa wirausaha merupakan perkumpulan orang yang dapat membuat/menagkap suatu ide dari peluang yang dilakukan secara terorganisir.

Sementara itu wirausaha dikemukakan oleh menurut Hendro, (2011:29) mengemukakan bahwa wirausaha sebagai peran utama pada pembangunan ekonomi serta memiliki fungsi nyata merupakan langkah yang inovatif atau kombinasi dapat dilakukan sebagai inovasi yang berikutnya. Wirausaha merupakan individu yang bebas dan memiliki kemampuan untuk menciptakan hal baru dengan ide dan kreatifitas sehingga memunculkan inovasi-inovasi yang sangat baik untuk dapat menjalankan usahanya dan dalam mengelola dan mengendalikan usahanya tersebut. Individu yang memiliki kemampuan berwirausaha tentunya tidak bisa berdiam diri menerima nasibnya, namun terus bergerak untuk memperbaiki taraf hidup agar bisa menjadi lebih baik. Sejatinya pelaku usaha dari waktu ke waktu tidak dapat hanya menunggu keadaan namun mereka malah harus dapat menciptakan keadaaan.

Menurut Redja Hudyaharjono (2012:10) para mahasiswa/peserta didik yang mendapatkan mata kuliah kewirausahaan di perguruan tinggi dapat memiliki nilai hakiki dan bekal karakter dalam berwirausaha sehingga dapat meningkatkan minat untuk menjadi wirausaha. Zimmerer, Scarborough dan Wilson (2008:20) mengemukanan bahwa hal yang mendorong dan manjadi fakto tumbuh kembangnya kewirausaha dalam pada sebuah negeri/negara dimana terdapat peran universitas, dalam hal ini penyelenggara pendidikan, khususnya bidang kewirausahaan. Mulai dari perkuliahan dalam bentuk perkuliahan di kelas, seminar maupun pendidikan dalam workshop kewirausahaan. Sudah sepatutnya peranan universitas dapat turut serta dalam memikul beban untuk dapat mendidik dan memberikan pendidikan yang baik pada bidang kewirausahaan. Sehingga para lulusan universitas benar-benar telah mampu mengadopsi dan mengimplmentasi akan ilmu pada bidang kewirausahaan tersebut.

Permatasari dan Agustina (2018), mengemukakan bahwa minat merupakan kegiatan terhadap hal pada pelibatan untuk menemukan, melakukan evaluasi dan mengembangkan atau mengekspolitasi diri terhadap kesempatan dalam hal dapat menciptakan produk atau jasa dan melakukan pengenalan kepada khalayak umum yang dapat diterima (dalam hal ini) dijual sehingga memiliki nilai jual yang profitable dengan menggunakan cara yang dapat dikatakan baru setidaknya dapat diterima oleh masyarakat. Dari uraian tersebut dapat disederhanakan bahwa minat merupakan keinginan untuk menciptakan atau membuat hal 
baru berupa produk atau jasa yang memiliki nilai jual dan memberikan hasil. Dengan demikian dapat memberikan peluang untuk memiliki nilai yang bernilai. Minat (interest) adalah suatu keinginan/hasrat dan/atau antusiasme terhadap seuatu hal yang diinginkan, (Muhibbin Syah, 2011). Hal ini menambahkan pengertian minat yang dibekali dari sebuah hasrat dengan antusias agar dapat berpartisipasi untuk menjadikan individu yang dapat disukai oleh orang lain dan memiliki cara untuk mempelajari keinginannya lebih dalam lagi. Lain halnya (Muchammad, 2014) mengemukakan bahwa minat adalah sebuah tindakan yang tidak akan lepas dari perasaan seseorang terhadap keinginan dan kesenangan akan suatu hal yang berdampak positif terhadap kegiatan yang ingin dilakukannya dan memberikan keyakinan yang kuat untuk melakukannya.

Motivasi menurut (Pramudyo, 2011) dalam Faisal, 2017 mengemukakan bahwa motivasi merupakan kondisi dapat digerakan ke arah tujuan yang diketahui dan saling berkaitan pada kewajibannya. Sementara itu seperti yang diungkapkan Robin (2008:222) dalam Faisal, 2017 berpendapat bahwa motivasi adalah sebuah kesediaan agar dapat mengeluarkan tingkatan tinggi pada tujuan dimana kondisi ini dilihat dari kemampuan dari upaya tersebut agar dapat memenuhi kebutuhan individu. Dapat disimpulkan bahwa motivasi adalah sebuah dorongan digerakan pada individu untuk melakukan suatu hal yang dilakukan atas kesediaan/telah menerima apa yang akan dilakukannya. Selain itu kegiatan yang dilakukan sepenuhnya untuk dapat memenuhi kebutuhan individu itu sendiri. Lain hal yang dikemukakan oleh Wahjosumidjo dalam Rusdiana (2014:70) menyebutkan motivasi merupakan sebuah proses yang berasal dari psikologi seseorang yang mencerminkan pada interaksi dari sikap, kebutuhan, persepsi serta keputusan yang dapat terjadi pada setiap individu berupa nilai kepribadian, sikap, pengalaman, dan pendidikan yang berasal dari dalam diri setiap individu itu sendiri.

Selain itu dapat disimpulkan bahwa setiap kegiatan atau perbuatan yang dilakukan merupakan rangkaian dari setiap pengalaman, ceminan sikap, pendidikan dan kepribadian setiap individu. Suryana (2013) berpendapat bahwa yang menjadi faktor dalam keberhasilan setiap orang/individu dalam berwirausaha itu terbagi menjadi 3 yang pertama adalah kemampuan dan kemauan. Maksudnya adalah memiliki pengetahuan dalam hal mampu menjalankan dan tahu bagaimana proses berwirausaha dan memiliki kemauan untuk menjalankannya. Memiliki kemampuan tapi tidak ada kemauan dalam menjalankannya sama saja tidak akan berhasil. Kedua yaitu tekad yang kuat dan kerja keras. Kemampuan dan kemauan saja tidak cukup namun diimbangi dengan tekat yang kuat artinya adalah dalam proses menjalankan usahanya perlu tekat yang kuat jika dalam perjalanannya ada kendala dana tau kegagalan sekalipun.

Berdasarkan kajian pustaka mengenai determinan keberhasilan wirausaha mahasiswa yang dikaji dari sudut pendidikan kewirausahaan, motivasi dan minat maka dapat disampaikan dimana kerangka pemikiran pada riset ini yaitu sebagai berikut: 


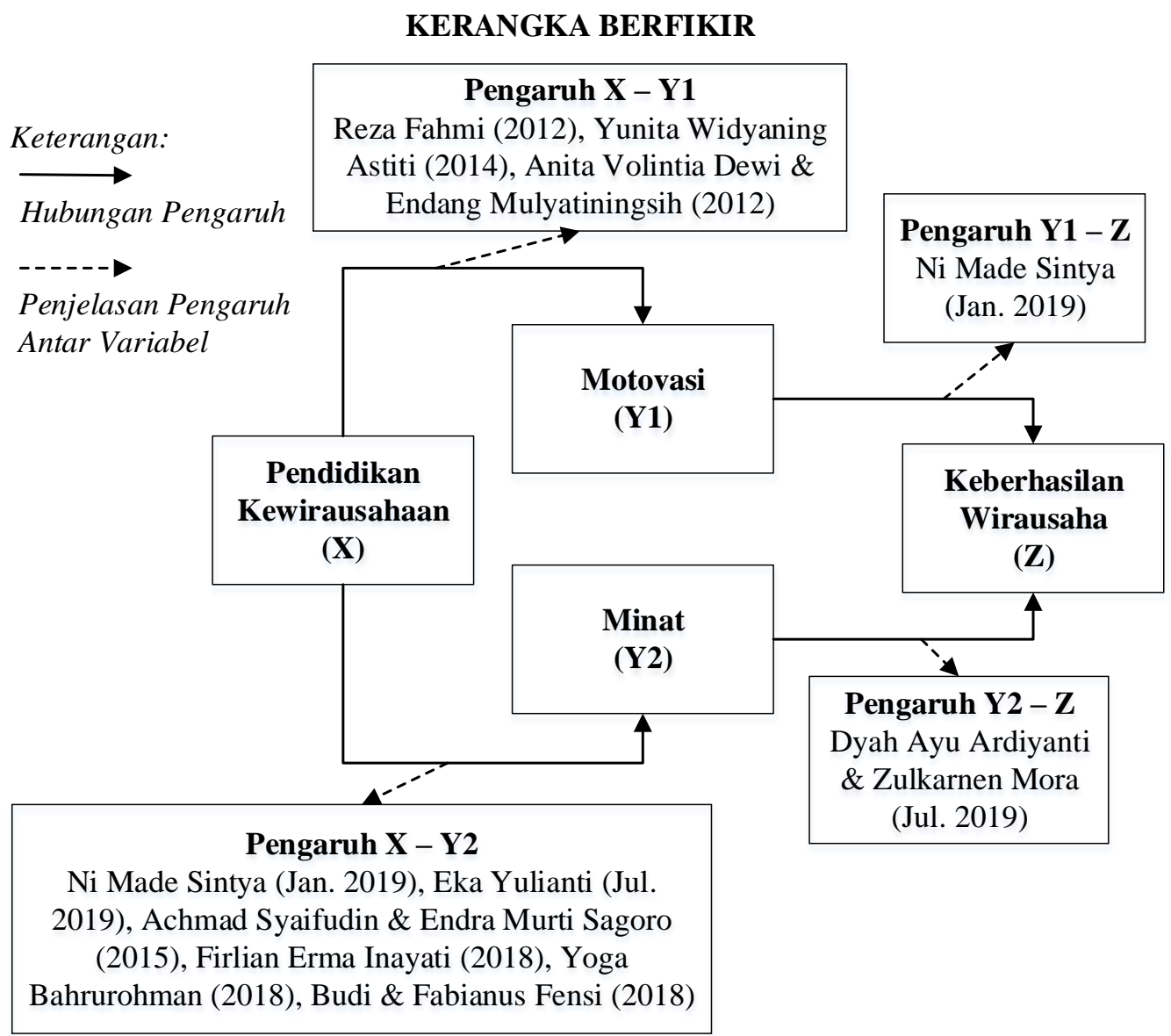

Suharsini (2012: 71) menjabarkan bahwa hipotesis merupakan sebuah feedback atau jawaban yang memiliki sifat tidak berkelanjutan pada masalah yang diteliti, hingga dapat dibuktikan oleh sajian data didapat. Lain lagi seperti pendapat Sugiyono (2012: 35) menerangkan hipotesis yaitu jawaban yang tidak selalu didapat sama dengan rumusan sebelum dilakukan uji data hingga didapati bahwa masalah yang diteliti dan juga rumusan dari masalah yang diteliti telah benar dan dinyatakan dapat berbentuk seperti kalimat tanya atau pernyataan. Sehingga dalam kajian teori dan uraian dari kerangka yang dipikirankan oleh peneliti dapat diuji hipotesis sebagai berikut:

1. Pendidikan kewirausahaan memiliki dampat yang positif terhadap motivasi wirausaha Mahasiswa di Tangerang Selatan.

2. Pendidikan kewirausahaan memiliki dampak yang positif terhadap minat wirausaha Mahasiswa di Tangerang Selatan

3. Motivasi wirausaha berpengaruh positif terhadap keberhasilan wirausaha Mahasiswa di Tangerang Selatan.

4. Minat wirausaha berpengaruh positif terhadap keberhasilan wirausaha Mahasiswa di Tangerang Selatan. 


\section{METODOLOGI PENELITIAN}

Dari data pada penelitian ini yaitu bersifat kuantitatif dengan menggunakan metode kuantitatif deskriptif yang dibatasi oleh satu masalah dan keadaan yang sebenarnya. Penelitian ini bersifat juga seperti mendeskripsikan yang bermaksud membuat deskripsi mengenai situasi dan kejadian sehingga disimpulkan bahwa penelitian ini dapat menggambarkan keadaan yang sedang berlangsung pada waktu tersebut yang didapat karena fakta yang diperoleh dari responden secara langsung. Populasi penelitian ini merupakan Mahasiswa aktif yang terdaftar di Universitas/Perguruan Tinggi yang ada wilayah Kota Tangerang Selatan yang telah mendapatkan pembelajaran Mata Kuliah Kewirausahaan yang akan diambil sampel data populasi. Pemilihan agar sampel dapat digunakan menurut rumus slovin sebagai berikut:

Dimana:

$$
N=\frac{N}{N \cdot d^{2}+1}
$$

$\mathrm{N} \quad=$ Jumlah Populasi

$\mathrm{n} \quad=$ Jumlah Sampel

$d^{2} \quad=$ Prosentase rerata dari ketidaktelitian dari tingkat sampel yang diambil memiliki masalah yang dapat ditolelir atau diinginkan sebanyak 10\% dari tingkat kepercayaan $95 \%$

Metode dalam pengambilan data dikumpulkan dengan media angket atau kuisioner. Structural Equation Modeling (SEM) adalah model dari Teknik statistik pada penelitian yang digunakan peneliti agar dapat dibangun dan diuji dari model statistik pada model yang terbentuk oleh atau disebab-akibatkan dengan penjelasan kerangka pemikiran. Populasi yang diteliti dan dijadikan objek/subjek yaitu para mahasiswa/l yang sedang menimba ilmu di pendidikan tinggi di Kota Tangerang Selatan. Sementara Sample dalam penelitian ini yaitu mahasiswa/l yang sedang dan/atau telah menempuh pendidikan khususnya mata kuliah kewirausahaan di Kota Tangerang Selatan. Adapun jumlah populasi yang berada dalam ruang lingkup dari tempat penelitian diketahui diuraikan di tabel berikut:

Tabel Jumlah Populasi yang Diteliti

\begin{tabular}{|l|r|r|}
\hline \multicolumn{1}{|c|}{ Universitas } & \multicolumn{1}{c|}{ Jumlah Mahasiswa } \\
\cline { 2 - 3 } & \multicolumn{1}{c|}{$\mathbf{2 0 1 8}$} & \multicolumn{1}{c|}{$\mathbf{2 0 1 9}$} \\
\hline Universitas Pamulang & 71011 & 74217 \\
\hline UIN Syarif Hidayatullah & 34162 & 25957 \\
\hline Institut Teknologi Indonesia & 3568 & 3242 \\
\hline $\begin{array}{l}\text { Universitas Muhammadiyah Jakarta Kampus } \\
\text { Tangerang Selatan }\end{array}$ & 22896 & 23135 \\
\hline Politeknik Keuangan Negara STAN & 10199 & 37 \\
\hline Universitas Terbuka & 1019328 & 1042017 \\
\hline Swiss German University & 805 & 763 \\
\hline Universitas Pembangunan Jaya & 1806 & 2598 \\
\hline
\end{tabular}




\begin{tabular}{|l|r|r|} 
STIKES Banten & 575 & 668 \\
\hline JUMLAH & $1,164,350$ & $1,172,634$ \\
\hline
\end{tabular}

Sumber : https://pddikti.kemdikbud.go.id/ diakses 05 Agustus 2020

Populasi yang dijadikan objek/subjek penelitian adalah para mahasiswa/i yang sedang menimba ilmu di pendidikan tinggi di Kota Tangerang Selatan berdasarkan data tahun 2019. Dimana untuk total populasi dalam penelitian ini yaitu sebanyak $1,172,634$ mahasiswa yang terdata dalam website resmi PDDIKTI Kemendikbud. Untuk dapat memenuhi capaian dalam penelitian ini, berdasarkan populasi tersebut bahwa sampel diperlukan untuk membuktikan bahwa variable yang diteliti memiliki pengaruh atau tidak. Sementara pengertian sample seperti yang dikemukakan oleh Sugiyono (2016:149) yaitu merupakan bagian sejumlah dan adanya karakteristik yang ada pada populasi tersebut.

Teknik pengujian data analisis menggunakan PLS-Structural Equation Modeling (PLSSEM). Penggunaannya diperuntukan untuk model statistic yang diuji adalah model sebab akibat. Penggunaan SEM ini diperlukan guna mendapatkan hasil statistik yang tepat untuk penelitian ini sehingga luaran dari penelitian ini dapat memenuhi kebutuhan yang diperlukan. Penggunaan teknik SEM ini yang disebut sebagai sebuah alat statistik yang diharapkan dapat mengakomodir dari variable-variabel. Tahapan berikutnya adalah cara lain agar data yang digunakan atau metode analisis seperti apa data yang digunakan. Langkah yang dapat dilakukan yaitu merupakan atau sebagai langkah agar dalam melakukan penelitian ini dapat ditemukan, dikembangkan dan tentunya dapat menemukan, uji mengenai suatu penelitian yang benar terkait substansi dari penelitian ini. Sehingga karya ilmiah yang dihasilkan ini dapat berguna dan dapat memenuhi kebutuhan berikutnya dan yang tidak kalah penting adalah tercapainya penelitian yang tepat dan terarah dengan menggunakan metode ilmiah sesuai dengan penelitian ini. Untuk mengumpulkan data variabel Pendidikan Kewirausahaan sebagai variable (X), sementara Motivasi (Y1) dan Minat (Y2) yang merupakan bagian turut mempengaruhi Keberhasilan Wirausaha sebagai variable (Z). Total angket atau kuesioner sebanyak 60 pertanyaan, dimana dalam pembagian setiap indikator yang diteliti adalah 15 pertanyaan/pernyataan tentang variable Pendidikan kewirausahaan, 15 pertanyaan/pernyataan tentang variable Keberhasilan usaha, 15 pertanyaan/pernyataan tentang variable motivasi wirausahan dan terkahir yaitu sebanyak 15 pertanyaan/pernyataan mengenai variable Minat usaha yang diteliti dalam penelitian ini. Dengan demikian setiap variable tersebut dapat diuji bagaimana hasilnya.

Instrument penelitian ini yang dilakukan adalah pengukuran dengan imbal hasil atau tujuan berupa data kuantitatif yang diharapkan dapat lebih akurat, sehingga dalam penelitian ini menggunakan skala likert. Secara umum teknik ini yaitu dengan melakukan dan/atau pemberian nilai/skor yang menjadi standar dalam penggunaan pada teknik skala likert ini. Seperti yang dikemukakan oleh Sugiyono (2012:231). Berikut tabel skor dari perhitungan skema likert :

Tabel Skala Likert

\begin{tabular}{|c|c|}
\hline Jawaban & Nilai \\
\hline SS (Sangat Setuju) & 5 \\
\hline S (Setuju) & 4 \\
\hline
\end{tabular}




\begin{tabular}{|c|c|}
\hline $\mathrm{R}$ (Ragu-ragu) & 3 \\
\hline TS (Tidak Setuju) & 2 \\
\hline $\begin{array}{c}\text { STS (Sangat Tidak } \\
\text { Setuju) }\end{array}$ & 1 \\
\hline
\end{tabular}

Sumber: Sugiyono (2012:231), dalam (Anthoni \& Faisal 2019).

\section{HASIL DAN PEMBAHASAN}

Diagram lajur pada gambar dibawah dilakukan kalkulasi menggunakan aplikasi SmartPLS berdasarkan nilai loading factor yang diperoleh pada masing-masing indikator, maka loading factor dengan nilai dibawah 0,4 akan dihilangkan dari model. (Hair et.al., 2011) sehingga hasil keluaran berupa gambar diagram lajur seperti gambar:

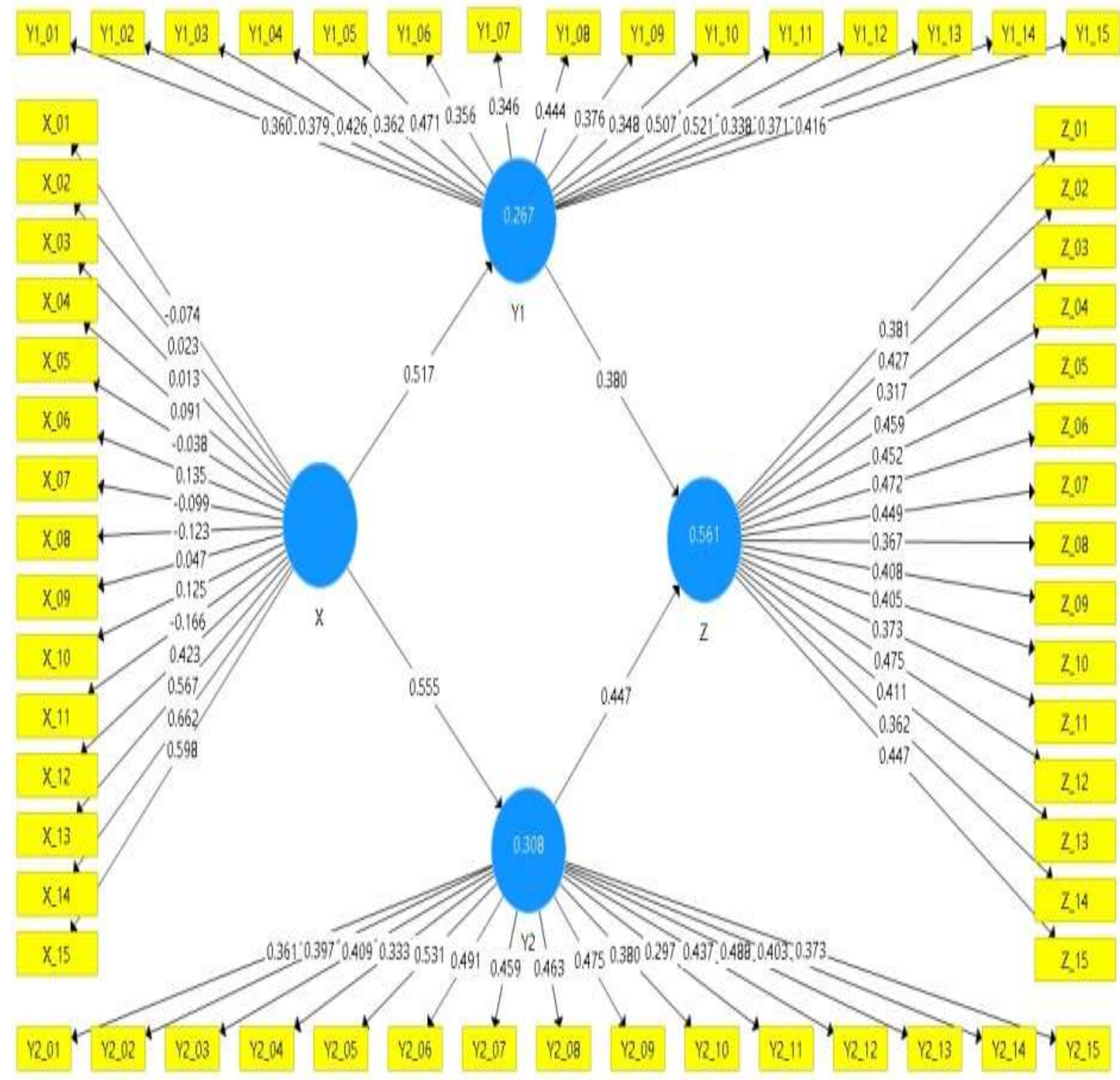


Loading factor yang bernilai kuran dari 0,4 dikeluarkan dari model, selanjutnya dilakukan reestimasi sampai semua indikator pada model PLS-SEM memiliki loading factor lebih besar dari 0,4 seperti gambar:

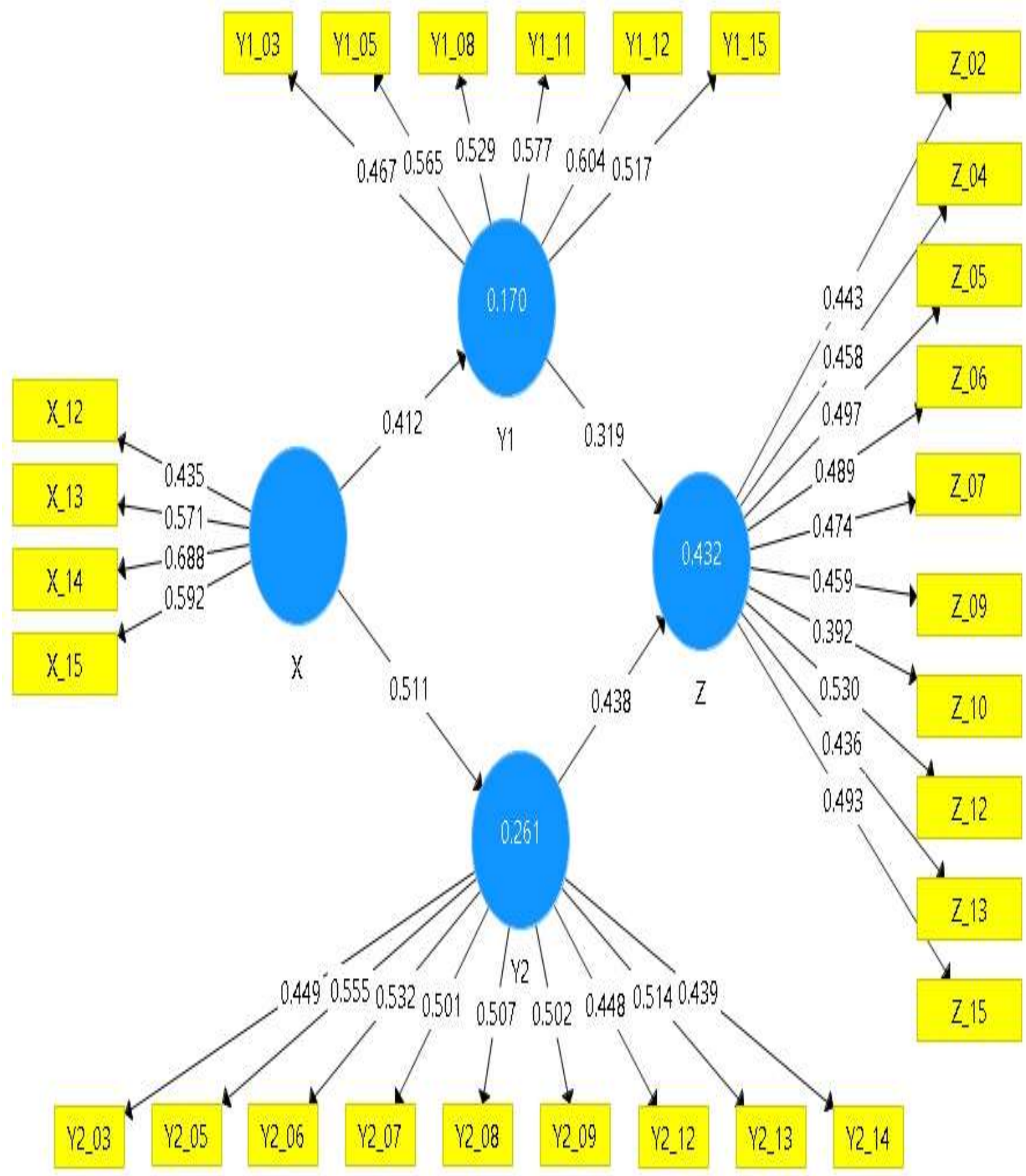

Model akhir SmartPLS-SEM pada gambar diatas telah memenuhi convergent validity, dimana indikator dengan loading factor kurang dari 0,4 telah dikeluarkan yang berarti bukan tidak penting melainkan indikator tersebut sangat sedikit berpengaruh dan tidak mencerminkan variabel latennya. 
Nilai dari outer loadings atau muatan bagian luar dari model akhir PLS-SEM menghasilkan tabel sebagai berikut:

Tabel Outer Loadings

\begin{tabular}{|l|l|l|l|l|}
\hline & X & Y1 & Y2 & $Z$ \\
\hline X_12 & 0.435 & & & \\
\hline X_13 & 0.571 & & & \\
\hline X_14 & 0.688 & & & \\
\hline X_15 & 0.592 & & & \\
\hline Y1_03 & & 0.467 & & \\
\hline Y1_05 & & 0.565 & & \\
\hline Y1_08 & & 0.529 & & \\
\hline Y1_11 & & 0.577 & & \\
\hline Y1_12 & & 0.604 & & \\
\hline Y1_15 & & 0.517 & & \\
\hline Y2_03 & & & 0.449 & \\
\hline Y2_05 & & & 0.555 & \\
\hline Y2_06 & & & 0.532 & \\
\hline Y2_07 & & & 0.501 & \\
\hline Y2_08 & & & 0.507 & \\
\hline Y2_09 & & & 0.502 & \\
\hline Y2_12 & & & 0.448 & \\
\hline Y2_13 & & & 0.514 & \\
\hline Y2_14 & & & 0.439 & \\
\hline Z_02 & & & & 0.443 \\
\hline Z_04 & & & & 0.458 \\
\hline Z_05 & & & & 0.497 \\
\hline Z_06 & & & & 0.489 \\
\hline Z_07 & & & & 0.474 \\
\hline Z_09 & & & & 0.459 \\
\hline Z_10 & & & & 0.392 \\
\hline Z_12 & & & & 0.530 \\
\hline Z_13 & & & & 0.436 \\
\hline Z_15 & & & & 0.493 \\
\hline Sumber: data diolah, 2020 \\
\hline
\end{tabular}

Nilai dari outer loadings pada tabel diatas menunjukkan pengaruh variabel laten terhadap indikatornya masing-masing. Outer loadings untuk variabel laten $X$ dengan 4 indikatornya dengan penafsiran variabel laten $X$ ke $X \_12$ senilai 0.435 sehingga dapat dilihat bahwa besarnya pengaruh atau dampak dari variabel laten $X$ pada indikator X_12 sebesar 0.435 . Nilai ini memiliki jumalh besarnya dampak/pengaruh variabel pendidikan kewirausahaan 
terhadap indikator X_12 adalah sebesar 0.435 . Penafsiran ini berlaku untuk variabel dan indikator berikutnya.

Koefisien Jalur atau Path Coefficientsdari model akhir PLS-SEM menghasilkan tabel Path Coefficient sebagai berikut:

Tabel Path Coefficients

\begin{tabular}{|l|l|l|l|l|}
\hline & $\mathbf{X}$ & $\mathbf{Y 1}$ & $\mathbf{Y}$ & $\mathbf{Z}$ \\
\hline $\mathbf{X}$ & & 0.412 & 0.511 & \\
\hline $\mathbf{Y} 1$ & & & & 0.319 \\
\hline $\mathbf{Y} 2$ & & & & 0.438 \\
\hline $\mathbf{Z}$ & & & & \\
\hline \multicolumn{5}{|c|}{ Sumber: data diolah, 2020 }
\end{tabular}

Nilai Path Coefficient pada tabel diatas menunjukkan besarnya pengaruh variabel laten terhadap variabel laten yang terhubung langsung dengan diagram jalur. Penafsiran koefisien jalur dari variabel laten $X$ ke variabel laten $Y 1$ sebesar 0.482 dampak atau variabel pendidikan kewirausahaan memang dipengaruhi oleh variabel $X$, dimana variabel minat senilai 0.412 dan variabel pendidikan kewirausahaan dipengaruhi oleh variabel motivasi sejumlah 0.511 . Sementara pengaruh total atau total effect dari model akhir PLSSEM pada gambar dibawah ini menghasilkan tabel total effect sebagai berikut:

Tabel Total Effect

\begin{tabular}{|l|l|l|l|l|}
\hline & $\mathbf{X}$ & $\mathbf{Y 1}$ & $\mathbf{Y 2}$ & $\mathbf{Z}$ \\
\hline $\mathbf{X}$ & & 0.412 & 0.511 & 0.355 \\
\hline $\mathbf{Y 1}$ & & & & 0.319 \\
\hline $\mathbf{Y 2}$ & & & & 0.438 \\
\hline $\mathbf{Z}$ & & & & \\
\hline \multicolumn{4}{|c|}{ Sumber: data diolah, 2020 } \\
\hline
\end{tabular}

Nilai Total Effect pada tabel diatas menunjukkan besarnya pengaruh variabel laten $X$ terhadap variabel laten $Z$ melalui variabel laten $Y 1$ dan $Y 2$ adalah sebesar 0.355 . sedangkan besarnya pengaruh variabel laten $Y 1$ terhadap variabel laten $Z$ adalah sebesar 0.319 , kemudian besarnya pengaruh variabel laten $Y 2$ terhadap variabel laten $Z$ adalah sebesar 0.438 .

Nilai dari R Square dari model PLS-SEM menghasilkan tabel R Square yaitu: Tabel R Square

\begin{tabular}{|l|r|}
\hline & R Square \\
\hline Y1 & 0.170 \\
\hline Y2 & 0.261 \\
\hline$Z$ & 0.432 \\
\hline
\end{tabular}

Sumber: data diolah, 2020

Dari tabel tersebut dapat dilihat bahwa nilai R-Square yang menunjukkan besarnya pengaruh variabel laten $X$ dengan masing-masing indikatornya ke $Y 1$ sebesar 0.170 , 
sedangkan besarnya pengaruh variabel laten $X$ dengan masing-masing indikatornya ke $Y 2$ sebesar 0.261 . selanjutnya besarnya pengaruh variabel laten $X$ dengan masing-masing indikatornya ke $Z$ melalui variabel $Y 1$ dan $Y 2$ sebesar 0.432 .

Nilai Average Variance Extracted (AVE) yang diwakili oleh indikator pada blok unitnya. Sehingga didapat nilai AVE untuk variabel laten X sejumlah 0.335 menggambarkan secara nilai rata-rata sejumlah $33,5 \%$ dari informasi pada tiap indikator dapat terlihat melalui variabel pendidikan kewirausahaan. Penjelasan ini berlaku sebagai gambaran pada tabel berikut ini:

Tabel Average Variance Extracted (AVE)

\begin{tabular}{|l|r|}
\hline & Average Variance Extracted (AVE) \\
\hline $\mathbf{X}$ & 0.335 \\
\hline $\mathbf{Y 1}$ & 0.297 \\
\hline $\mathbf{Y} 2$ & 0.245 \\
\hline $\mathbf{Z}$ & 0.220 \\
\hline \multicolumn{3}{|c|}{ Sumber: data diolah, 2020 } \\
\hline
\end{tabular}

Untuk mengukur konsistensi internal dapat dilihat dari nilai Composite Reliability, dimana harus memenuhi syarat nilai Composite Reliability diatas 0.6 (Ghozali, 2014; Sarwono \& Narimawati, 2015).

Tabel Composite Reliability
\begin{tabular}{|l|r|}
\hline & Composite Reliability \\
\hline $\mathrm{X}$ & $\mathbf{0 . 6 6 3}$ \\
\hline $\mathrm{Y} 1$ & $\mathbf{0 . 7 1 5}$ \\
\hline $\mathrm{Y} 2$ & $\mathbf{0 . 7 4 4}$ \\
\hline $\mathbf{Z}$ & $\mathbf{0 . 7 3 7}$ \\
\hline
\end{tabular}
Sumber: data diolah, 2020

Berdasarkan tabel Composite Reliability diatas pada variabel laten $\mathrm{X}$ sejumlah 0.633 , variabel laten $\mathrm{Y} 1$ sebesar 0.715 , variabel laten $\mathrm{Y} 2$ sebesar 0.744 dan variabel laten $\mathrm{X}$ sebesar 0.737 . keempat nilai composite reliability tersebut diatas nilai 0.6 sehingga dapat dijelaskan bahwa pengukuran konsistensi internal pada variabel-variabel tersebut semuanya berada diatas nilai persyaratan standar.

Untuk mengetahui besarnya korelasi antara variabel laten, dapat dilakukan dengan melihat nilai latent variable correlations atau korelasi antar variabel laten seperti tabel berikut ini:

Tabel Correlation Antar Variabel

\begin{tabular}{|l|r|r|r|r|}
\hline & \multicolumn{1}{|l|}{$\mathbf{X}$} & $\mathbf{Y 1}$ & $\mathbf{Y 2}$ & $\mathbf{Z}$ \\
\hline $\mathbf{X}$ & 1.000 & 0.412 & 0.511 & 0.420 \\
\hline $\mathbf{Y 1}$ & 0.412 & 1.000 & 0.497 & 0.537 \\
\hline $\mathbf{Y 2}$ & 0.511 & 0.497 & 1.000 & 0.596 \\
\hline $\mathbf{Z}$ & 0.420 & 0.537 & 0.596 & 1.000 \\
\hline
\end{tabular}

Sumber: data diolah, 2020 
Berdasarkan tabel diatas korelasi antara variabel laten $\mathrm{X}$ dengan $\mathrm{Y} 1$ sebesar 0.412 mempunyai makna variabel $X$ memiliki hubungan sebesar 0.412 dengan variabel $Y 1$. korelasi antara variabel laten $X$ dengan $Y 2$ sebesar 0.511 mempunyai makna variabel $X$ memiliki hubungan sebesar 0.511 dengan variabel $Y 2$. korelasi antara variabel laten $X$ dengan $Z$ sebesar 0.420 mempunyai makna variabel $X$ memiliki hubungan sebesar 0.420 dengan variabel $Z$. Penjelasan tersebut berlaku sebagai keterangan dan gambaran dari tabel diatas.

Untuk melakukan pengujian hipotesis, maka dilakukan perbandingan antara t0 dan ta. Ketentuan penerimaan hipotesis dari ketentuan, dimana to $>$ ta artinya $\mathrm{H} 0$ ditolak dan $\mathrm{H} 1$ dapat diterima, sedangkan dimana t0 < ta artinya $\mathrm{H} 0$ dapat diterima, namun $\mathrm{H} 1$ ditolak. Untuk menentukan besarnya nilai t tabel maka tingkat signifikansi yang digunakan atau nilai alpha adalah sebesar 0.1 atau $10 \%$. Dari degree of freedom (df) sejumlah data -2 atau n-2, sehingga dengan data sebanyak 417 maka nilai df sebesar 415. Dengan mekanisme tersebut, diperoleh nilai t-tabel atau ta sebesar 2.335 .

Tabel Hasil Pengujian Hipotesis

\begin{tabular}{|c|c|c|c|c|c|}
\hline No. & Item & t0 & ta $^{*}$ & Ketentuan & Hipotesis \\
\hline 1 & $\mathrm{X}--->\mathrm{Y} 1$ & 9.863 & 2.335 & $\mathrm{t} 0>\mathrm{ta}$ & $\mathrm{H} 0$ ditolak; $\mathrm{H} 1$ diterima \\
\hline 2 & $\mathrm{X}-->\mathrm{Y} 2$ & 15.838 & 2.335 & $\mathrm{t} 0>\mathrm{ta}$ & $\mathrm{H} 0$ ditolak; $\mathrm{H} 1$ diterima \\
\hline 3 & $\mathrm{Y} 1--->\mathrm{Z}$ & 7.222 & 2.335 & $\mathrm{t} 0>\mathrm{ta}$ & $\mathrm{H} 0$ ditolak; $\mathrm{H} 1$ diterima \\
\hline 4 & $\mathrm{Y} 2--->\mathrm{Z}$ & 10.502 & 2.335 & t0 $>$ ta & H0 ditolak; $\mathrm{H} 1$ diterima \\
\hline
\end{tabular}

Keterangan:

Sumber: data diolah, 2020

- ${ }^{*}=$ significance level $10 \%$

- $\quad t$ tabel 2.335 (significance level 10\%)

Tabel diatas merupakan tabel hasil penelitian uji hipotesis dengan penjelasan pada poin 1 menunjukkan t0 lebih besar dari pada ta, dengan demikian $\mathrm{HO}$ ditolak dan $\mathrm{H} 1$ dapat diterima. Sehingga disimpulkan yaitu variabel $X$ memiliki dampak/pengaruh pada variabel Y1 secara signifikan.Pada poin 2 menunjukkan to lebih besar dari pada ta, dengan demikian $\mathrm{HO}$ ditolak dan $\mathrm{H} 1$ dapat diterima. Oleh karena itu disimpulkan untuk variabel $\mathrm{X}$ juga berdampak/berpengaruh pada variabel Y2 secara signifikan. Pada poin 3 menunjukkan t0 lebih besar dari pada ta, dengan demikian HOditolak dan $\mathrm{H} 1$ dapat diterima. Oleh akrena itu, variabel $Y 1$ memiliki dampak/pengaruh pada variabel $Z$ secara signifikan. pada poin 4 menunjukkan to lebih besar dari pada ta, dengan demikian H0ditolak dan H1 dapat diterima. Selanjutnya dapat dikatakan variabel Y2 memiliki dampak kepada variabel Z secara signifikan. 


\section{E. KESIMPULAN}

Berdasarkan pemaparan diatas, menunjukkan t0 lebih besar dari pada ta, sehingga $\mathrm{HO}$ ditolak dan $\mathrm{H} 1$ dapat diterima. Hal ini terlihat dan disimpulkan yakni variabel $\mathrm{X}$ memiliki dampak/pengaruh pada variabel $Y 1$ secara signifikan. Selain itu didapatkan bahwa variabel $\mathrm{X}$ juga memiliki dampak/pengaruh pada/terhadap variabel $\mathrm{Y} 1$ secara signifikan. Pada poin 2 menunjukkan t0 lebih besar dari pada ta, sehingga $\mathrm{H} 0$ ditolak dan $\mathrm{H} 1$ dapat diterima. Berdasarkanhal tersebut maka variabel $X$ memiliki pengaruh pada variabel $Y 2$ secara signifikan. Pada poin 3 menunjukkan to lebih besar dari pada ta, sehingga HO ditolak dan $\mathrm{H} 1$ dapat diterima. Maka disimpulkan yaitu variabel Y1 memiliki dampak/pengaruh pada variabel $Z$ secara signifikan. Pada poin 4 menunjukkan to lebih besar dari pada ta, sehingga daidapati bahwa $\mathrm{H} 0$ ditolak dan $\mathrm{H} 1$ dapat diterima. Selanjutnya secara keseluruhan bahwa variabel $\mathrm{Y} 2$ juga berdampak/berpengaruh pada variabel $\mathrm{Z}$ secara signifikan.

Adapun saran pada hasil penelitian ini adanya peningkatan materi pembelajaran pendidikan kewirausahaan dalam hal metode dan update permasalahan, solusi dan informasi bisnis diasumsikan dapat memberikan pengaruh terhadap keilmuan, pengetahuan dan wawasan mahasiswa agar berhasil dalam berwirausaha. Dukungan berbagai pihak dalam memberikan pengarahan, penyuluhan maupun sosialisasi termasuk sarana dan prasarana pembelajaran berwirausaha diharapkan dapat memberikan hal baru dalam usaha kewirausahaan.

\section{DAFTAR PUSTAKA}

Aidha, Z. 2016. Pengaruh Motivasi terhadap Minat Berwirausaha Mahasiswa Fakultas Kesehatan Masyarakat Universitas Islam Sumatera Utara.

Aini, Yulfita (2015). Pengaruh Pembelajaran Kewirausahaan Terhadap Minat Mahasisw UPP Berwirausaha. Jurnal IImia Cano Ekonomos, Vol. 3 No. 1.

Alizar Hasan, Insanul Kamil, Siti Tri Susiati Hatami, Perancangan Alat Ukur Kriteria Keberhasilan Wirausaha Baru (Studi Kasus: PMW Universitas Andalas). Jurnal IImia Teknik Industri.

Alma, B. 2011. Kewirausahaan untuk Mahasiswa dan Umum. Bandung: Alfabeta.

Ardiyanti, Dyah Ayu \& Mora, Zulkarnen, (2019). Pengaruh Minat Usaha dan Motivasi Usaha terhadap Keberhasilan Usaha Wirausaha Muda di Kota Langsa. Jurnal Samudra Ekonomi dan Bisnis, Vol. 10, No. 2.

Astiti, Yunita Widyaning. (2014). Pengaruh Pendidikan Kewirausahaan Terhadap Motivasi Berwirausaha dan Keterampian Berwirausaha Mahasiswa Pendidikan Ekonomi Universitas Negeri Yogyakarta.

Bahrurohman, Yoga. 2018). Pengaruh Pendidikan Kewirausahaan, Efikasi Diri dan Kesiapan Instrumen Wirausaha Terhadap Minat Berwirausaha Mahasiswa (Studi pada Mahasiwa FEB di PTN dan PTS Sukoharjo.

Basrowi. (2011). Kewirausahaan untuk Perguruan Tinggi. Bogor: Ghalia Indonesia.

Bruyat, C., \& Julien, P.-A. (2000). Defining the Field of Research in Entrepreneurship,Journal of Business Venturing, p. 165-180.

Budi \& Fensi, Febianus, (2018). Pengaruh Pendidikan Kewirausahaan dalam Menumbuhkan Minat Berwirausaha, Jurnal Pengabdian dan Berwirausaha, Vol 2, No. 1.

Dewi, Anita Volintia \& Mulyatiningsih, Endang. (2013). Pengaruh Pengalaman Pendidikan Kewirausahaan dan Keterampilan Kejuruan Terhadap Motivasi Berwirausaha Siswa. Jurnal Pendidikan Vokasi, Vol. 3, No. 2. 
Devi, Abrista. (2017). Peran Orientasi Kewirausahaan Sebagai Mediasi Antara Pendidikan dan Minat Berwirausaha pada Mahasiswa. Jurnal Studi Ekonomi dan Bisnis Islam. Vol 2 No. 2.

Eny, Eko Sulistyowati, Utomo, Sugeng Hadi \& Sugeng, Bambang. (2016). Pengaruh Pendidikan Kewirausahaan di Lingkungan Keluarga, Pembelajaran Kewirausaha di Sekolah serta Achievement Motive terhadap Minat Kewirausahaan Siswa SMA. Jurnal Pendidikan, Vol. 1, No. 11.

Edy Purwo Saputro, Nur Achmad, Sih Handayani (2016). Identifikasi Faktor yang Mempengaruhi Sukse Wirausaha, Jurnal Vol. 1 No 1, Juni 2016 P10-20.

Fahmi, Reza. (2012). Pengaruh Pembelajaran Kewirausahaan Terhadap Motivasi Berwirausaha. Vol. 1 No. 2, (2012).

Faisal, Rahman (2017) Pengaruh Rotasi dan Kompetensi Terhadap Motivasi karyawan Non Dosen STEI ITB. Jurnam Manajemen dan Jurnal Akuntansi Vol. 2, No. 1 Tahun 2017, P460-497.

Ferdinand, A., 2002. Structural Equation Modeling Dalam Penelitian Manajemen. Edisi Kedua. Semarang: Badan Penerbit Undip.

Fitriati, R., \& Hermiati, T (2010). Entrepreneurial Skills and Characteristics Analysis on the Graduates of the Department of Administrative Sciences, FISIP Universitas Indonesia. Journal of Administrative ScienceS \& Organization, p. 262-275.

Hansemark, O. C. (2003). Need for Achievement, Locus of Control and the Prediction of Business Start-ups: A Longitudinal Study. Journal of Economic Psychology, 24(3), 301-319.

Hendro. 2011. Dasar-Dasar Kewirausahaan. Panduan bagi Mahasiswa untuk Mengenal, Memahami, dan Memasuki Dunia Bisnis. Jakarta: Erlangga.

Heinonen, J., \& Poikkijoki, S.-A. (2006). An entrepreneurial-directed approach to entrepreneurship education: mission impossible? Journal of Management Development, p. 80-94.

H.A. Rusdiana. (2014). Kewirausahaan Teori dan Praktik. Bandung: CV PUSTAKA SETIA Muhibbin Syah. 2011. Psikologi Belajar. Jakarta: Rajawali Pers.

Inayati, Firlian Erma, (2018). Pengaruh Pendidikan Kewirausahaan, Sikap, Lingkungan Keluarga dan Motibasi Terhadap Minat Berwisausaha. Universitas Islam Indonesia.

Koranti, Komsi. 2013. Analisis Pengaruh Faktor Eksternal dan Internal Terhadap Minat Berwirausaha. Proceeding PESAT. (Psikologi, Ekonomi, Sastra, Arsitektur \& Teknik Sipil). Vol. 5. Jurusan Manajemen. Fakultas Ekonomi. Universitas Gunadarma.

Lesmana, R., Widodo, A. S., \& Sunardi, N. (2020). The Formation of Customer Loyalty From Brand Awareness and Perceived Quality through Brand Equity of Xiaomi Smartphone Users in South Tangerang. Jurnal Pemasaran Kompetitif, 4(1), 1-12.

Lesmana, R. (2017). Pengaruh Citra Perusahaan Terhadap Keputusan Pembelian Konsumen PT. Garuda Indonesia Tbk.(Persero). JIMF (Jurnal IImiah Manajemen Forkamma), 1(1).

Lesmana, R., \& Hasbiyah, W. (2019). Model Analisis Kepuasan dan Loyalitas Wisatawan Lokal Studi Kasus pada Objek Wisata Kepulauan Seribu Jakarta. JIMF (Jurnal IImiah Manajemen Forkamma), 2(3).

Lesmana, R. (2019). Analisis Strategi Bersaing PT Dwi Perkasa Mobiltama Pamulang untuk Meningkatkan Penjualan. JIMF (Jurnal IImiah Manajemen Forkamma), 3(1).

Muchammad Arif Mustofa. 2014. Pengaruh Pengetahuan Kewirausahaan, Self Efficacy, dan Karakter Wirausaha terhadap Minat Berwirausaha pada Siswa Kelas XI SMK Negeri 1 Depok Kabupaten Sleman. Skripsi. Yogyakarta: Universitas Negeri Yogyakarta.

Moberg, K (2012). An Entrepreneurial Self-Efficacy Scale with a Neutral Wording' Djøf / Juristog Økonomforbundet, Frederiksberg. SMG Working Paper, 2012 (6).

Jurnal Pemasaran Kompetitif, Vol. 4 No. 1 Oktober 2020 
Nursalina. 2018. Faktor-Faktor yang Mem- pengaruhi Keberhasilan Usaha Mikro Kecil Berbasis Ekonomi Kreatif di Kota Makasar. Skripsi. Makasar: Universitas Negeri Makasar.

Permatasari, A., \& Agustina, A. (2018) Entrepreneurial Behaviour among Undergraduate Business, Social and Engineering Students: A Case of Private. Indonesian University. Jurnal Manajemen Indonesia, 18(2), 94-110.

Permatasari, Anggreani, Nugraha, Rendika \& Hadiansah, Ihsan. (2018). Analisis Relevansi Pendidikan Kewirausahaan dan Lingkungan Kampus Terhadap Minat Berwirausaha Mahasiswa Perguruan Tinggi di Jawa Barat, Indonesia. Conference on Managemen anda Behavioral Sudies,

Prawirokusumo, Soeharto. 2010. Kewirausahaan dan Manajemen Usaha Kecil. Edisi Pertama. Yogyakarta : BPFE_Yogyakarta.

Prihantoro, Wisnu Septian Ginanjar, (2015). Pengaruh Pendidikan Kewirausahaan, Motivasi Berwirausaha dan Lingkungan Keluarga Terhadap Mental Kewirausahaan Siswa SMK Negeri 1 Demak (Studi Pada Siswa Kelas XI Pemasaran Tahun Ajaran 2014/2015). Skripsi di Fakultas Ekonomi, Universitas Negeri Semarang.

Putri, Ni Luh Wahyuni Widya. 2014. Pengaruh Pendidikan Kewirausahaan Terhadap Minat Mahasiswa untuk Berwirausaha pada Mahasiswa Pendidikan Ekonomi Universitas Pendidikan Ganesha.

Raposo, M., \& Paço, A. (2011). Entrepreneurship education: Relationship between education and entrepreneurial activity. Psicothema, p. 453-457.

Retno Budi Lestari dan Trisnandi Wijaya. (2012). Pengaruh Pendidikan Kewirausahaan Terhadap Minat Berwirausaha Mahasiswa di STIE MDP, STMIK MDP, dan STIE MUSI. Jurnal IImiah STIE MDP, Volume 1, Nomor 2, Maret 2012. HIm. 112-119.

Rifkhan. 2017. Pengaruh Sikap, Dan Motivasi Terhadap Minat Berwirausaha Mahasiswa Akuntasi Universitas Pamulang. Skripsi. Universitas Pamulang.

Sarwono, Jonathan \& Narimawati, Umi. (2015). Membuat Skripsi, Tesis, dan Disertasi Partial Least Square SEM (PLS-SEM). Yogyakarta: C.V ANDI OFFSET

Rusdiana. H.A. 2014. Kewirausahaan: Teori dan Praktek. Bandung: Pustaka Setia.

Sevilla, Consuelo G. et. al (2007). Research Methods. Rex Printing Company. Quezon City

Sintya, Ni Made. (2019). Pengaruh Motivasi, Efikasi Diri, Ekspektasi Pendapatan, Lingkungan Keluarga dan Pendidikan Kewirausahaan Terhadap Minat Berwirausaha Mahasiswa Jurusan Akuntansi di Universitas Mahasaraswati Denpasar. Jurnal Sains, Akuntansi dan Manajemen. Vol. 1, No. 1.

Suharbayu, Iwan. (2017) Pengaruh Pendidikan Kewirausahaan, Lingkungan Keluarga dan Keberanian Menanggung Resiko dalam menumbuhkan Minat Berwirausaha Mahasiswa Program Studi Manajemen Fakultas Ekonomi Universitas Nusantara PGRI Kediri. Jurnal Simki-Economic Vol. 01 No. 02.

Sugiyono. 2014. Metode Penelitian Bisnis. Bandung: Alfabeta.

Sugiyono. 2015. Statistika untuk Penelitian. Bandung: Alfabeta.

Sunardi, N., Lesmana, R., \& Tumanggor, M. (2018). Implementasi Manajemen Dalam Meningkatkan Iman Dan Taqwa Masyarakat Dusun Panyeredan, Cimanggu, Cisalak, Subang-Jawa Barat. Jurnal Pengabdian Dharma Laksana, 1(1), 131-140.

Suryana. 2013. Kewirausahaan (Kiat dan Proses Menuju Sukses). Jakarta: Salemba Empat.

Suryana, Yuyus. Bayu, Kartib. 2010. Kewirausahaan Pendekatan Karakteristik Wirausahawan Sukses. Edisi Kedua. Jakarta : Kencana

Syarifudin, Achmad \& Sagoro, Enra Murti, (2017). Pengaruh Kepribadian, Lingkungan Keluarga dan Pendidikan Kewirausahaan Terhadap Minat Berwirausaha Mahasiswa Akuntansi. Jurnal Profita Edisi 8 Tahun 2017. 
Tuskeroh, 2013. Pengaruh Motivasi dan Mental Berwirausaha pada Mahasiswa Akuntansi Universitas Maritim Raja Ali Haji.

Utami, Made Ayu Pratiwi dan Sari, Maria Mediatrix Ratna. 2017. Pengaruh Motivasi Internal dan Motivasi Eksternal Terhadap Minat Berwirausaha Mahasiswa Jurusan Akuntansi Non Reguler. E-Jurnal Akuntansi Universitas Udayana. Vol. 20.

Winardi. 2001. Kepemimpinan dan Manajemen. Jakarta: Rineka Cipta

Yuniasanti, Reni dan Esterlita, Santi, Pengaruh Pendidikan Kewirausahaan Terhadap Intensi Berwirausaha mahasiswa Universitas Mercu Buana Yogyakarta.

Yuliyanti, Eka. 2019. Pengaruh Sikap Mandiri, Motivasi dan Pengetahuan Kewirausahaan Terhadap Minat Mahasiswa Berwirausaha Secara Syariah di Institut Pertanian Bogor.

Zimmerer, Thomas W., dkk. (2008). Kewirausahaan dan Manajemen Usaha Kecil. Jakarta: Salemba Empat.

60 persen produk Usaha Kecil Menengah di Tangerang Selatan Didominasi Kuliner, http://wartakota.tribunnews.com/2018/09/05/60-persen-produkusaha-kecil-menengah-di-tangerang-selatan-didominasi-kuliner, diakses pada Jum'at, 09 Agustus 2019.

Pelayanan Publik. Jakarta: Menteri Negara Pendayagunaan Aparatur Negara. 